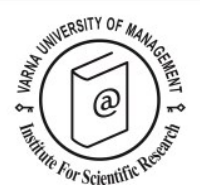

\title{
Restaurant assessment of local food and the Global Sustainable Tourism criteria
}

\author{
Robert S. Bristow ${ }^{1 *}$ and lan Jenkins ${ }^{2}$ \\ Received: 19/07/2016 Accepted: 27/05/2017
}

\footnotetext{
1 Department of Geography and Regional Planning, Westfield State University, Westfield MA 01086 USA. Tel: 1-413-572-5215 (O), 1-413-572-5470 (F). E-mail: rbristow@westfield.ma.edu

${ }^{2}$ School of Engineering \& Natural Sciences, Sæmundargötu 2, University of Iceland, 101 Reykjavík, Iceland. Email: jenkins@hi.is

* Corresponding author
}

\begin{abstract}
Certification standards have evolved to become a recognizable achievement in businesses. For tourism, numerous models have risen recently and most are striving to reach broad acceptance. The assessment utilized in this study was the management model suggested by the Global Sustainable Tourism Criteria (GSTC). From the food service perspective, little research has been devoted to exploring the willingness to adopt sustainable practices by restaurant managers. In order to assess the relevancy of the GSTC, a sample of restaurants located on several islands of the Turks and Caicos (TCl), the Pioneer Valley region of Massachusetts, U.S., in Wales, U.K. and Southern Switzerland were asked to rate the importance of several of the GSTC. Several differences in managements' rating of sustainable practice were found, illustrating the unique geographies of our sample. Overall however, management embraced the importance of the GSTC.
\end{abstract}

(C) 2018 Varna University of Management. All rights reserved

Keywords: Global Sustainable Tourism Criteria, food, sustainability, management.

Citation: Bristow, R., I. Jenkins (2018) Restaurant assessment of local food and the Global Sustainable Tourism criteria. European Journal of Tourism Research 18, pp. 120-132

\section{Introduction}

Frequently identified as a fundamental tool for economic development, sustainable tourism has an important role in today's world (Butler, 1999; Sharpley, 2000). Numerous models of sustainability have been proposed over the years. Most built on the need for resource protection (e.g. clean water), promotion of economic development (jobs), long term benefits (social discounting) and protecting local values (culture). These are all important goals of a sustainability model, and as such, The United Nations Millennium Development Goals stress that these should be embraced by the tourism industry (Bricker et al., 2012). One possible model is the Global Sustainable Tourism Criteria that have evolved to be a set of standards tourism operators should strive to achieve. The Criteria were developed by United Nations sustainability experts and the tourism 
industry and based on more than 60 existing models of sustainable tourism certification already deployed around the world.

Yet sustainability remains an elusive term. Born out of the Environmental Movement of the 1960s and '70s, sustainability is often labeled as a "green approach". Drexhage and Murphy (2010) have noted the definition is often not understood by the public and if that is the case, industry must also be struggling with the concept. Early green approaches pursued problems of waste reduction, recycling and the re-use of resources. There are many resources to consider and the one under investigation here is food. Other than composting, since food is perishable and not something that can be recycled or re-used in the tourist experience, one needs to look at food as a resource for (human) consumption in a holistic setting that includes the local economy, social welfare and political environs.

Contemporary food and tourism research has been wide and varied. From the perspective of restaurant management, research has been devoted to the tourists desire to seek and experience local foods (Cohen \& Avieli, 2004; Herzog \& Murray, 2013; Hughes \& Lew, 2013; Nilsson, 2013; Broadway, 2015), resulting from the partnerships between agriculture and tourism (Timms, 2006; Everett \& Slocum, 2013) and the linkages between consumers and producers (Torres, 2002; Ashley et al., 2006; Feagan; 2007; Green \& Dougherty, 2008, Everett, 2013).

Beyond this important research, little study has been devoted to exploring the willingness of sustainable practices by restaurant managers. Given the tremendous carbon footprint that food production has on the environment (Hillier et al., 2009; Gössling et al., 2011), the more actions taken by the food service industry in terms of purchasing policies and the day to day management, the more likely the business will become sustainable.

The next section of the paper introduces food as an important factor in the tourist experience by highlighting local sourced diets and the biotechnical and other recent production methods used to increase quantity of food for a growing and changing demand. Following this, sustainable management practices for tourist businesses are introduced. The methods employed in this study are then described and the sample is defined. Management's ranking of importance for local food, type of food production systems and sustainable management practices are then summarized and the paper concludes with an assessment of the Global Sustainable Tourism Criteria as viewed by management and suggests future research needs.

\section{Literature Review}

Eating is an important ingredient of the tourist experience (Everett \& Aitchison, 2008; Everett, 2008; Sims, 2009; Mehmetoglu \& Normann, 2013). Food is defined by not only the particular item, that is meat versus vegetable, but where it comes from, how it is prepared and how it might relate to the mood or taste of the diner. All of these elements impact the availability of certain menus the tourist may face. For the purpose of this study and the relevancy in sustainability in tourism, three areas of literature are highlighted. First is an attempt to introduce food and the migration toward a more sustainable diet. Second, we are challenged by defining local food and the connection to the food service industry. And third, an exploration into the changing production processes of food that tourists are now expecting in their menu is identified. These three themes contribute to an understanding of sustainable management practices facing restaurants in a variety of destinations today.

Food consumption has changed dramatically around the world. Globally our taste for meats, vegetable oils and wheat has increased tremendously over the past four decades (Kearney, 2010). As producers are faced with this insatiable appetite, increased yields of food has become essential. More food and faster growth is needed. The result is food and drink based on increased mechanization. Despite this fundamental shift in consumption, this diet has met with some opposition as diners now desire organic menus or fish sourced from sustainable stocks as part of a "slow food" movement (Petrini, 2003). These simple foods are believed to be safer for consumption and more sustainable as the impact of production is minimized. 
Price distance between consumer and producer and perceived or real availability of sustainable foods are typically the primary concerns raised by consumers (Robinson \& Smith, 2002; Vermeir \& Verbeke, 2006; Thompson \& Kidwell, 1998). These concerns are mirrored by management as well (Jokinen, Järvelä, \& Puupponen, 2009). Even though price remains an important aspect in the food service industry, current data has found consumers are willing to pay more for "green" practices by tourist providers (Choi et al., 2009; Dutta et al., 2008; Schubert et al., 2010).

This is an important consideration for tourism since food expenses while travelling range from $25-33 \%$ of the total cost of a trip (Hudman, 1986; Meler \& Cerović, 2003). Given this high portion of the tourist's budget, restaurants are found to be an important determinant in the consumer's choice of a destination (Sparks et al., 2003). This leads to the question of what tourists are eating.

\section{Local food}

Recent attention to local food's attraction for tourists has grown and challenges researchers since it is multidimensional and complex (Murdoch et al., 2000; Allen \& Hinrich, 2007; Feagan, 2007; Frisvoll, Forbord \& Blekesaune, 2016) and for that matter what constitutes sustainable foods (Robinson \& Smith, 2002; Scarpato, 2002). Local cuisine has long been recognized to contribute to a region's identity (Bessière, 1998; du Rand, Heath \& Alberts, 2003; du Rand \& Heath, 2006; Sims, 2009; Everett \& Slocum, 2013; Nelson, 2016). In a study of factors influencing consumer behavior, $31 \%$ of the participants rated local food as very influential in their decision (Sparks et al., 2003). Eating local food and drink is believed to potentially reduce energy consumption by shortening supply lines, protect unique agricultural and culinary traditions, preserve scenic agricultural landscapes and agrobiodiversity, and provide just compensation for producers and laborers (Kloppenburg et al., 1996; Pollan, 2007; Sims, 2009). These goals dovetail with tourists' interests in experiencing the uniqueness of places and regions.

Building on the attention to the destination, research by Buller and Morris (2004) and
Torres and Momsen (2004) found that tourist's desire for local foods can create opportunities to develop sustainable agriculture and help the local economy. Timms (2006) recommends that the local farmer/producers strengthen community organizations and focus on long term capacity building to link the farmers with the tourism industry. This type of ecological entrepreneurship, as Marsden and Smith (2005) call it, enhances the attraction of a specific destination by building a culinary network involving local food producers and food related experiences. The clear advantage of networks and cooperation between producers may yield the quality and quantity needed for tourism (du Rand and Heath, 2006; Rogerson, 2012). This in turn may explain that smaller locally owned tourism operations purchase more local food than do larger foreign owned operations (Momsen, 1998).

Locally sourced food is also an important element used to promote economic and societal vitality in a region (Feenstra, 1997; Pearson, Henryks \& Jones, 2011; Ferreira \& Hunter, 2017). But since not all tourist destinations can produce enough in quantity and variety for the needs of diners, much of food must still be imported in a region. So even if local food is grown, in many cases it is exported to outside markets that are willing to pay higher prices creating another financial obstacle to smaller restaurants.

There are many ways to measure "local" and there is no real consensus on how to measure "food miles" as it applies to local food (DEFRA, 2005; Pratt, 2013). Based on the challenges of the different modes of transport, pre-processing of food and packaging, distance measured is a relative term. Do local foods have to be entirely local? Is the food native to the area, or has it been imported and locally grown? These difficulties and more make it extremely difficult to establish what is local and what is not. The perception of local food is frequently paired with organic and other natural processes, a measurable dimension for food tourists (Robinson \& Getz, 2016). This feeds a link to the next section of the paper.

\section{Food Production}

In recent decades, beyond the source customers are interested in foods believed to 
be more naturally produced or grown. Food production techniques have become an important aspect for the provision of food for a growing population (Kearny, 2010). Notwithstanding this demand, there is a growing hunger to return to basics and obtain quality foods that have not been adulterated by residual chemicals. Included in this list would be organic and chemical free foods, pesticide free food obtained from an integrated pest management farm strategy, grass fed and free range animals, food free of genetically modified organisms and fish sourced from a certified sustainable stock.

For example, organic food is one item that is frequently craved by consumers (Kearny, 2010). Organic foods have long been a staple of farmer's markets where they are often available (Hall, 2013) and are now a common item found on the grocer's shelves. Organic food typically employs farming practices that minimize or reduce chemicals used against insects and other vegetation or to improve growth.

Diners are also concerned about how the animals may be treated. Grass fed and free range animals are some of the more important practices since the animal's diet and wellbeing can influence the quality of the meat (Telfer and Wall, 1996; Bureau and Valceschini, 2003). Food from Genetically Modified Origins (GMO) is seen as one way to feed the world's growing population. However, despite this noble claim, GMO is not without its opponents (Hall \& Gössling, 2013). For the tourist, assessing this risk varies whether they are home or away. GMO was found to be viewed as relatively risk free at home, but away from home, tourists judged the risk to be significantly higher (Larsen et al., 2007).

Seafood consumption has dramatically increased worldwide (Pauly et al., 2002; Pauly, 2008). The EU, Japan and the US are major consumers of fish transported thousands of miles from foreign stocks (Swartz, et al., 2010). As a result, globalization of the "Common Fishing Grounds", seafood is threatened by overfishing and pollution. To protect the resource, fish from certified sustainable stock ensure the species is protected. Diners have been exposed to numerous educational attempts to identify impacts of fishing certain species and seafood guides provide an understanding of the environmental impacts (Roheim, 2009).

In summary, there are many strategies to increase the quantity of food produced. Tourists' attention to food that is more natural and more representative of the local cuisine is now what is at stake.

\section{Sustainable Tourism}

As reported earlier, food is a major cost for tourists. And while cost is important, research has found a link between tourists' assessment of local food with that of supporting sustainable consumption (Slocum, 2015). Since cuisine has been shown to contribute to the destinations identity, how can a tourist business meet the demand and achieve a level of sustainability?

Sustainability is used to describe a process that minimizes impacts and maximizes benefits to society. Numerous models of tourism sustainability have been explored over the past decades. And in 2002, there were as many as 260 voluntary tourism initiatives around the globe (Black, 2012). Whatever model is used to build sustainable management practices in tourism, the need to address social, economic and environmental factors is needed to meet the United Nations Millennium Development Goals (Bricker et al., 2012).

The Global Sustainable Tourism Criteria as prepared in 2009 is being evaluated in this study (GSTC, 2010). The Criteria were developed by United Nations sustainability experts and the tourism industry and based on more than 60 existing models of sustainable tourism certification already deployed around the world. They are organized around four main themes: effective sustainability planning; maximizing social and economic benefits for the local community; enhancing cultural heritage; and reducing negative impacts to the environment. The GSTC model is founded on the desire to create baseline guidelines for businesses, both large and small, to become more sustainable and to serve as a starting point for the more specific needs of governments, NGO's and the private sector. 
Since deployment in late 2008 , the criteria are being critiqued at the management level.

In order to ascertain the importance of environmental, social and economic concerns facing restaurant businesses, ten of the Criteria were selected for this study. Each addresses several of the impacts restaurant management face.

The literature above examines a number of studies that contribute to an understanding of sustainability in eating outside of the home. Linking relevant tourism literature with food, especially under the theme of sustainability for restaurant businesses has been presented. This paper takes that initial exploration one step further by employing a management study instead of the more typical approach of surveying the tourist alone. To achieve a broad sample of management views on sustainable practices, as prescribed by the GSTC, four unique geographies are sampled. In the next section of the paper describes the data collection process, methodology and survey instrument.

\section{Methodology}

To explore restaurant managements' importance of local food, food production processes and sustainable practices, a survey was prepared. Specifically the survey collected information on the particular cuisine offered, size of operation in terms of seating and staff and sources of food. The menu questions inquired about production practices (e.g., organic, grass fed, free range and so on). Finally a series of statements prepared by the GSTC were evaluated by restaurant management. These criteria are designed to assess the importance of sustainability measures to managers.

After pre-testing, the questionnaire was then administered in four locations: the Turks and Caicos Islands (a British Territory) during the summer of 2011, Western Massachusetts in the US in the Fall of 2011, Switzerland, Spring 2012, and Wales in the UK, Summer 2012. Excluded from the sample were chain and fast food restaurants because purchasing and management policies may not be locally controlled. A convenience survey was then delivered in person to a manager or head chef and completed through an interview process or left for management to complete on their own and picked up the next day or returned by mail.

All in all 77 complete surveys were collected, yielding an approximate $28.9 \%$ response rate across the four locations. Though an estimate of the population size in each area could be determined, given the nature of food businesses where frequent openings and closures exist on a regular basis, our estimated sample size is just that, an estimate.

\section{Results}

A variety of restaurants were surveyed and the size ranged from 15 to 150 seats with an average of 75 seats. An assortment of cuisines was offered with the most common being American (52.8\%), Caribbean (28.3\%), Italian (28.3\%), Seafood (24.5\%) and Vegetarian (24.5\%). A few restaurants noted Asian, BBQ, Cajun, Steak and other styles on their menu. Since most restaurants offered more than one type of food on their menu, the percentages overlap.

The next section of the survey solicited information about the sources of food. For this study a temporal measure of local is proposed instead of a spatial one. Two hours or less is suggested as local and is measured from producer to the restaurant. Times greater are no longer local. Managers were asked to identify sources of food on a 1 to 5 scale with "1" being all food of this type is local, "2" most of the food is local, " 3 " some of the food is local, and " 4 " where none of the food is local. If the restaurant did not offer a type of food, it was coded " 5 " for does not serve.

For our sample, baked goods tended to be locally sourced with most of the food being local (All Local 51.9\%), whereas for meats, poultry and dairy were more likely imported (None Local $31.2 \%, 32.5 \%, 32.5 \%$ respective). Only nine restaurants did not serve seafood. Further, while nineteen $(24.7 \%)$ of the restaurants reported that none of their beverages were local, it is not surprising given the manufacturing of soft drinks and production of spirits are typically always imported. Table 1 summarizes the sources of food across the sample. 
Table 1. Food Sources for Restaurant Study.

\begin{tabular}{llllll}
\hline Food & All Local & Most Local & Some Local & None Local & Does not Serve \\
\hline Meats & $12(15.6)$ & $19(24.7)$ & $18(23.4)$ & $24(31.2)$ & $0(0)$ \\
Poultry & $11(14.3)$ & $21(27.3)$ & $14(18.2)$ & $25(32.5)$ & $1(1.3)$ \\
Seafood & $20(26)$ & $23(29.9)$ & $11(14.3)$ & $9(11.7)$ & $9(11.7)$ \\
Dairy & $22(28.6)$ & $14(18.2)$ & $13(16.9)$ & $25(32.5)$ & $0(0)$ \\
Produce & $20(26)$ & $21(27.3)$ & $23(29.9)$ & $7(9.1)$ & $1(1.3)$ \\
Baked Goods & $40(51.9)$ & $17(22.1)$ & $7(9.1)$ & $6(7.8)$ & $5(6.5)$ \\
Beverages & $14(18.2)$ & $15(19.5)$ & $24(31.2)$ & $19(24.7)$ & $0(0)$ \\
\hline
\end{tabular}

Note: Frequency (percentage).

Table 2. Summary statistics for Food Production Techniques

\begin{tabular}{llllll}
\hline & $\begin{array}{c}\text { Very } \\
\text { Important }\end{array}$ & \multicolumn{1}{c}{ Important } & Indifferent & $\begin{array}{c}\text { Not } \\
\text { Important }\end{array}$ & $\begin{array}{c}\text { Not Very } \\
\text { Important }\end{array}$ \\
\hline Organic & $9(12.3)$ & $24(32.9)$ & $25(34.2)$ & $9(12.3)$ & $6(8.2)$ \\
Chemical Free & $17(23.3)$ & $22(28.6)$ & $22(28.6)$ & $10(13.7)$ & $2(2.7)$ \\
Integrated Pest Management & $16(22.5)$ & $16(22.5)$ & $26(36.6)$ & $10(14.1)$ & $3(4.2)$ \\
Grass Fed & $8(11.1)$ & $14(19.4)$ & $38(52.8)$ & $8(11.1)$ & $4(5.6)$ \\
Free Range & $13(17.8)$ & $18(24.7)$ & $32(43.8)$ & $7(9.6)$ & $3(4.1)$ \\
GMO Free & $15(21.1)$ & $19(26.8)$ & $25(35.2)$ & $8(11.3)$ & $4(5.6)$ \\
Fish Sourced & $24(33.8)$ & $21(29.6)$ & $14(19.7)$ & $10(14.1)$ & $2(2.8)$ \\
\hline
\end{tabular}

Note: Frequency (percentage).

Consumers frequently desire particular characteristics of their food. Diners want organic food, range free chickens, grass fed beef and so on in their menu. Managers are sensitive to these requests. Table 2 highlights the importance of these items on a five point Likert-type scale, from very important to not very important to management.

Fish sourced from sustainable stocks was the most important to management with $63.4 \%$ of the restaurants noting it was very important or important. Chemical free food was favored by management $51.9 \%$ of the time. On the other hand organic food was not important to $20.5 \%$ of the sample and this could reflect the lack of availability. Even though most food production methods may be valued by management, it became evident from the comments that importance did not mean available. In the Caribbean for example, other than organic produce from a local hydroponic farm, little other organic food was procurable. In other cases restaurants expressed no interest in these foods and would continue to buy items from local distributors.

Next, the managers were asked to assess the importance of several of the Global Sustainable Tourism Criteria. Ten of the Criteria were selected for this study and address environmental and economic impacts restaurant management face. All of the Criteria were important to managers. Table 3 provides the aggregate responses on a five point Likerttype scale, from "1" representing the most important to " 5 " for not very important.

Highest on the list was "The international or national legal protection of employees is respected, and employees are paid a living wage (mean $=1.56$ out of 5 ), "The purchase of disposable and consumable goods is measured, and the business actively seeks ways to reduce their use" (mean= 1.88), "Energy consumption should be measured, sources indicated, and measures to decrease overall consumption should be adopted, while encouraging the use of renewable energy" (mean=1.94) and "A solid waste management plan is implemented, with quantitative goals to minimize waste that is not reused or recycled" (mean=1.98).

In order to assess the differences in the importance of sustainable practices by the restaurant management in our sample, a Oneway Analysis of Variance was employed. Using the importance of the GSTC between the four locations, several significant differences were 
Table 3. Overall importance of Global Sustainable Tourism Criteria

\begin{tabular}{|c|c|c|c|}
\hline & $\mathbf{N}$ & Mean & Std. Dev. \\
\hline $\begin{array}{l}\text { Purchasing policy favors environmentally friendly products for } \\
\text { building materials, capital goods, food, and consumables. }\end{array}$ & 74 & 2.0541 & 0.96361 \\
\hline $\begin{array}{l}\text { The purchase of disposable and consumable goods is measured, } \\
\text { and the business actively seeks ways to reduce their use. }\end{array}$ & 76 & 1.9342 & 0.83802 \\
\hline $\begin{array}{l}\text { Energy consumption should be measured, sources indicated, and } \\
\text { measures to decrease overall consumption should be adopted, } \\
\text { while encouraging the use of renewable energy. }\end{array}$ & 76 & 2.0263 & 0.99296 \\
\hline $\begin{array}{l}\text { Water consumption should be measured, sources indicated, and } \\
\text { measures to decrease overall consumption should be adopted. }\end{array}$ & 76 & 2.1184 & 0.97935 \\
\hline $\begin{array}{l}\text { Greenhouse gas emissions from all sources controlled by the } \\
\text { business are measured, and procedures are implemented to } \\
\text { reduce and offset them as a way to achieve climate neutrality. }\end{array}$ & 75 & 2.5067 & 1.01839 \\
\hline $\begin{array}{l}\text { Wastewater, including gray water, is treated effectively and } \\
\text { reused where possible. }\end{array}$ & 74 & 2.1486 & 1.06864 \\
\hline $\begin{array}{l}\text { A solid waste management plan is implemented, with quantitative } \\
\text { goals to minimize waste that is not reused or recycled. }\end{array}$ & 75 & 1.9467 & 0.97111 \\
\hline $\begin{array}{l}\text { The use of harmful substances, including pesticides, paints, } \\
\text { swimming pool disinfectants, and cleaning materials, is minimized; } \\
\text { substituted, when available, by innocuous products; and all } \\
\text { chemical use is properly managed. }\end{array}$ & 71 & 1.7324 & 0.82735 \\
\hline $\begin{array}{l}\text { The business implements practices to reduce pollution from } \\
\text { noise, light, runoff, erosion, ozone-depleting compounds, and air } \\
\text { and soil contaminants. }\end{array}$ & 74 & 2.2568 & 0.98009 \\
\hline $\begin{array}{l}\text { The international or national legal protection of employees is } \\
\text { respected, and employees are paid a living wage. }\end{array}$ & 74 & 1.5000 & 0.66724 \\
\hline
\end{tabular}

found. A Tukey post hoc-test was selected to compare each of our locations against one another. Table 4 summarizes the mean scores of importance for each of the GSTC in each location. Significance levels and standard deviations are also provided.

Restaurant management ranked most of the criteria high. The ANOVA test found several criteria to be significantly different and of note are the differences found for energy use $(F(3,72)=2.999, \quad p=0.036)$, water use $(F(3,72)=6.747, p=0.000)$, and waste water $(F(3,70)=4.783, p=0.004)$. While not significant at the 0.05 level, a purchasing policy of environmental friendly products was significant at the 0.10 level $(F(3,70)=2.582, p=0.060)$. All other criteria were rated uniformly the same across the four locations and therefore are equally important to restaurant managers. We must note that even though the GSTC were important, the large standard deviation of "waste management" in the Switzerland sample indicates a wide variation of the importance for restaurants in that region.

Between the countries in our sample, the most significant differences are found between the United States and the Turks and Caicos Islands. One might suspect the unique geographies of food production and availability of these two locations contribute to the difference in the importance of tourist management strategies. Purchasing policies, energy use, water use and Mean responses within rows followed by different locations (TC=Turks and Caicos, US $=$ United States, SW=Switzerland, UK=United Kingdom) are significantly different at the 0.05 level.

Waste water disposal are significantly different in this pair of locations. This should be of no surprise for the reason that small islands have significant challenges when it comes to food 
Table 4. Results of ANOVA comparing differences between four locations.

\begin{tabular}{|c|c|c|c|c|c|c|}
\hline Variable & $\mathrm{TCl}$ & US & Swiss & UK & $\mathbf{F}$ & $\mathbf{P}$ \\
\hline \multicolumn{7}{|c|}{ Purchasing Policies } \\
\hline Mean & $1.66^{\mathrm{US}}$ & $2.35^{\mathrm{TC}}$ & 2.20 & 1.83 & 2.52 & 0.06 \\
\hline SD & 0.79 & 1.05 & 1.22 & 0.38 & & \\
\hline \multicolumn{7}{|c|}{ Disposable } \\
\hline Mean & 1.71 & 2.00 & 1.90 & 2.15 & 0.841 & 0.47 \\
\hline SD & 0.71 & 0.85 & 0.94 & 0.89 & & \\
\hline \multicolumn{7}{|l|}{ Energy } \\
\hline Mean & $1.52^{\mathrm{US}}$ & $2.22^{\mathrm{TC}}$ & 2.00 & 2.38 & 2.99 & 0.036 \\
\hline SD & 0.74 & 1.17 & 0.63 & 0.86 & & \\
\hline \multicolumn{7}{|l|}{ Water } \\
\hline Mean & $1.42^{\text {US }}$ & $2.54^{\mathrm{TC}}$ & 2.18 & 2.15 & 6.74 & 0.001 \\
\hline SD & 0.59 & 1.05 & 0.60 & 0.98 & & \\
\hline \multicolumn{7}{|c|}{ Greenhouse Gas } \\
\hline Mean & 2.23 & 2.61 & 2.50 & 2.29 & 0.73 & 0.53 \\
\hline SD & 0.88 & 1.02 & 1.08 & 1.18 & & \\
\hline \multicolumn{7}{|c|}{ Wastewater } \\
\hline Mean & $1.57^{\text {US }}$ & $2.54^{\mathrm{TC}}$ & 1.81 & 2.45 & 4.78 & 0.004 \\
\hline SD & 0.74 & 1.12 & 0.87 & 1.12 & & \\
\hline \multicolumn{7}{|c|}{ Solid Waste } \\
\hline Mean & 1.80 & 2.09 & 1.7 & 2.00 & 0.6 & 0.61 \\
\hline SD & 0.74 & 1.04 & 1.25 & 0.91 & & \\
\hline \multicolumn{7}{|l|}{ Harmful } \\
\hline Mean & 1.66 & 1.74 & 1.60 & 2.00 & 0.43 & 0.72 \\
\hline SD & 0.73 & 0.85 & 0.96 & 0.86 & & \\
\hline \multicolumn{7}{|l|}{ Pollution } \\
\hline Mean & 1.90 & 2.51 & 2.3 & 2.16 & 1.71 & 0.172 \\
\hline SD & 0.94 & 1.06 & 0.82 & 0.83 & & \\
\hline \multicolumn{7}{|l|}{ Wage } \\
\hline Mean & 1.38 & 1.67 & 1.40 & 1.33 & 1.29 & 0.28 \\
\hline SD & 0.49 & 0.7 & 0.96 & 0.49 & & \\
\hline
\end{tabular}

Note: Mean scores base on a 5 point Likert scale with 1 being very important and 5 being not very important.

sourcing and supplies (Pratt, 2013). What is of interest though, is the lack of significant differences when the island restaurants are compared to the sample across the Atlantic.

Conserving energy and water may be done out of necessity and help reduce costs of operation. Compared to the Turks and Caicos, where fresh water is obtained by desalinization plants, the other three countries have relatively ample water supplies. Still as Gössling et al. (2012) have found water consumption by tourists on a global scale is but one percent of the total consumption. They recommend that for regional deficits in dryer climates reduction and reuse of water is still prudent. On the other hand, both water and waste water criteria were generally less important to United States restaurants. This lack of interest however needs to be balanced with the fact that water availability is relatively inexpensive and plentiful in all regions except $\mathrm{TCl}$.

\section{Discussion}

The results indicate that restaurant managers assess the importance of local foods, food production practices and the GSTC relatively the same. That is, most are important yet given the cost, availability or practicality of using the food or executing the practice depends on the local milieu.

For example, baked goods are perishable and are generally very affordable. It makes sense to bake bread locally since it tends to be bulky, relatively light and not very expensive. Shipping bread great distances would drive the cost up too high for most restaurants. On the other 
hand meats and poultry can be frozen and have a higher cost per pound so might be transported great distances to meet the demand.

Our food production questions were all rated high in importance, but foods of this type are more likely to be found in specialized eateries that would promote themselves as serving natural foods. While some places may have grain-fed beef on the menu, the majority of the restaurants would not bother to serve this menu item. Fish sourced from sustainable stock was the most important food found in the sample and may reflect the management's interest in maintaining a viable supply for future consumption. Diners' preferences might also dictate management's sustainability interests. Where the client's income is higher, restaurants can explore more options to meet the need of this wealthier clientele. Local competition may also drive interest in sustainable practices; more research into the differences of restaurants might address this concern.

The GSTC were found to be universally accepted and important to restaurant management. Most differences existed between the samples of United States and the Caribbean. But even within the Caribbean, one would expect regional differences since islands with adequate rainfall and good soils would be able to produce enough food for their own population as well as meet the demand of neighboring islands less fortunate. For the restaurants in the $\mathrm{TCl}$, imports from both the US as well as the Dominican Republic contribute to the menu offerings because the local agricultural sector has not kept up with the growing tourist demand. Baked goods and seafood contribute to the local food for the islands.

Elsewhere in the sample, restaurants have an established and well stocked wholesale food delivery system in place. Where local food items are available, it is frequently dependent on the growing season, since no restaurant can entirely depend on local strawberries for their daiquiris year round. In today's marketplace, you can just about get any food from around the world, if you are willing to pay the price.

\section{Conclusion}

In this study restaurant management valued the GSTC. In many cases, it made monetary sense because the business costs could be quite high. Since food costs alone are typically $1 / 3$ of the operational expense of a restaurant, cost savings may help management reassess the importance of the practices as recommended by the GSTC. No matter what the cost, sustainable practices in the food service industry are an essential strategy for future planning (Gössling et al., 2011).

It should be expected that in the highly competitive tourist market of food service, restaurants that remain in business have balanced the costs of operations with meeting the needs of the customer. In the long run the customer determines which restaurants stay open. Restaurants prepare their menu based on a variety of foods tied to a particular cuisine. Once the menu is determined, management is faced with the task of procuring the best food possible to meet the demand. Food is highly perishable, so the business has to consider consumption and storage in this decision.

Just as there may be a range of tourists ranging from experienced to novices, the range of managers is likely to be as broad. Restaurants highly motivated to provide sustainable food are likely to work hard on achieving that goal.

Encouraging prospects do exist for the restaurants. In discussions with restaurants following the main survey, several managers indicated they would purchase more local food providing the cost, availability, and quality were dependable. Even though costs may be higher, given that tourists are willing to pay for authentic local food, it is likely the partnerships would be proven successful (Buller \& Morris, 2004; Torres \& Momsen, 2004). Additionally this kind of partnership has the benefit of increasing food security (Beckford, 2009). By insuring food production meets the needs of the local citizens, planners can maximize the benefits of this fundamental need. The restaurants in the study were all locally managed giving the operation more flexibility in the procuring of foods to meet the demand and 
balancing that cost against the labor and other expenses.

Even if restaurants cannot expand local food items on their menu, the issues raised with the GSTC can reduce the costs of operational significantly. The attention given to minimizing waste, energy use and other sustainable management practices encouraged by the GSTC will likely improve the tourism business. Differences exist due to the unique geographies across the sample, yet the interest is still high since management recognizes improving the sustainability can impact the performance of the café.

By testing the Global Sustainable Tourism Criteria across four different locales, we can suggest that the restaurant management's rating of the GSTC model has broad appeal. A recent study in Australia for example has shown the food and wine ecotourism operators are more likely to promote sustainable food than the eco-lodges and wildlife businesses (Fennell and Markwell, 2015). Thus it is up to the food service businesses to take the lead on sustainable practices since everyone eats. Future research could continue to explore the importance ranking of the GSTC, but also the actual purchasing behavior of restaurants in their attempt to improve sustainability. Budgeting for sustainability is needed since those tourist businesses who do not, may not be open the next time you visit.

\section{References}

Allen, P. \& Hinrich, C. (2007). Buying into 'Buy Local': Engagement. In D. Maye, L. Holloway. \& M. Kneafsey. Alternative Food Geographies: Representation and Practice. Oxford, UK: Elsevier, 255-272

Ashley, C. Goodwin, H., McNab, D. Scott, M., \& Chaves, L. (2006). Making tourism count for the local economy in the Caribbean. Pro-Poor Tourism Partnership and the Caribbean Tourism Organisation. URL: http://www.odi.org.uk/sites/odi.org.uk/files/ odi-assets/publications-opinionfiles/3013.pdf (Accessed on 1.7.2016)

Beckford, C. L. (2009). Sustainable agriculture and innovation adoption in a tropical small-scale food production system: The case of Yam Minisetts in Jamaica. Sustainability 1, 81-96.

Bessière, J. (1998). Local development and heritage: Traditional food and cuisine as tourist attractions in rural areas. Sociologia Ruralis 38, 21-34.

Black, R. (2012). Partnerships in Practice: Ecotourism and Sustainable Tourism Accreditation and Certification Programs. In K. Bricker, R. Black \& S. Cottrell. (Eds.). Sustainable tourism and the millennium development goals. Burlington, MA, Jones \& Bartlett Publishers, 277-295

Bricker, K., Black, R., \& Cottrell, S. (Eds.). (2012). Sustainable tourism and the millennium development goals. Burlington, MA: Jones \& Bartlett Publishers.

Broadway, M. (2015). Implementing the slow life in southwest Ireland: A case study of Clonakilty and local food. Geographical Review, 105(2), 216-234.

Buller, H., \& Morris, C. (2004). Growing goods: The market, state and sustainable food production. Environment and Planning $A$ 36, 1065-1084.

Bureau, J. C., \& Valceschini, E. (2003). European food-labeling policy: successes and limitations. Journal of Food Distribution Research 34: 70-76.

Butler, R. (1999). Sustainable Tourism: a Stateof-the-art review. Tourism Geographies 1, 7-25.

Choi, G., Parsa, H. G., Sigala, M., \& Putrevu, S. (2009). Consumers' environmental concerns and behaviors in the lodging industry: A comparison between Greece and the United States. Journal of Quality Assurance in Hospitality \& Tourism 10, 93-112.

Cohen, E., \& Avieli, N. (2004). Food in tourism: attraction and impediment. Annals of Tourism Research 31, 755-778.

DEFRA. (2005). The validity of food miles as an indicator of sustainable development. London: DEFRA.

du Rand, G. \& Heath, E. (2006). Towards a framework for food tourism as an element of destination marketing. Current Issues in Tourism 9, 206-234.

du Rand, G. E., Heath, E., \& Alberts, N. (2003). The role of local and regional food in destination marketing: A South African 
situation analysis. Journal of Travel and Tourism Marketing 14, 97-112.

Drexhage, J. \& Murphy, D. (2010). Sustainability Development: From Brundtland to Rio 2012. Background Paper for High level Panel on Global Sustainability. URL: http://www.un.org (Accessed on 15.5.2016)

Dutta, K., Umashankar, V., Choi, G., \& Parsa, H. G. (2008). A comparative study of consumers' green practice orientation in India and the United States: A study from the restaurant industry. Journal of Foodservice Business Research 11, 269-285.

Everett, S. \& Aitchison, C. (2008). The Role of Food Tourism in Sustaining Regional Identity: A Case Study of Cornwall, South West England. Journal of Sustainable Tourism 16, 150-167.

Everett, S. (2008). Beyond the visual gaze? The pursuit of an embodied experience through food tourism. Tourist Studies 8: 337-358.

Everett, S. (2013). Production places or consumption spaces? The place making agency of food tourism in Ireland and Scotland. Tourism Geographies 14, 535554.

Everett, S. \& Slocum, S. (2013). Food and tourism: An effective partnership? A UKbased review. Journal of Sustainable Tourism 21, 789-809.

Feagan, R. (2007). The place of food: mapping out the 'local' in local food systems. Progress in Human Geography 31, 23-42.

Feenstra, G. (1997). Local food systems and sustainable communities. American Journal of Alternative Agriculture 12, 28-36.

Fennell, D., \& Markwell, K. (2015). Ethical and sustainability dimensions of foodservice in Australian ecotourism businesses. Journal of Ecotourism 14(1), 48-63.

Ferreira, S. \& Hunter, C. (2017). Wine tourism development in South Africa: a geographical analysis. Tourism Geographies, 19(5), 676-698

Frisvoll, S., Forbord, M., \& Blekesaune, A. (2016). An empirical investigation of tourists' consumption of local food in rural tourism. Scandinavian Journal of Hospitality and Tourism, 16(1), 76-93.

Global Sustainable Tourism Criteria, GSTC. (2010). Global Sustainable Tourism
Criteria. Retrieved from http://new. gstcouncil.org/.

Gössling, S., Garrod, B., Aall, C., Hille, J., \& Peeters, P. (2011). Food management in tourism: Reducing tourism's carbon 'foodprint'. Tourism Management 32, 534-543.

Gössling, S., Peeters, P., Hall, C. M., Ceron, J. P., Dubois, G., Lehmann, L. V., \& Scott, D. (2012). Tourism and water use: Supply, demand, and security. Tourism Management 33, 1-15.

Green, G. P., \& Dougherty, M. L. (2008). Localizing linkages for food and tourism: Culinary tourism as a community development strategy. Community Development 39, 148-158.

Hall, C. (2013). The local in farmers' markets in New Zealand. In C. M. Hall \& S. Gössling, (Eds.). Sustainable Culinary Systems: Local Foods, Innovation, Tourism and Hospitality. (pp. 99-121) Abingdon, Routledge.

Hall, C., \& Gössling, S. (Eds.). (2013). Sustainable Culinary Systems: Local Foods, Innovation, Tourism and Hospitality. Abingdon: Routledge.

Herzog, C \& I. Murray. (2013). Is local just a hot menu item trend? Exploring restaurant patrons' menu choices when encountering local food options. In C. M. Hall \& S. Gössling, (Eds.). Sustainable Culinary Systems: Local Foods, Innovation, Tourism and Hospitality. Abingdon: Routledge, 122-134

Hillier, J., Hawes, C., Squire, G., Hilton, A., Wale, S., \& Smith, P. (2009). The carbon footprints of food crop production. International Journal of Agricultural Sustainability 7, 107-118.

Hudman, L. (1986). The travellers' perception of the role of food and eating in the tourist industry. Proceedings of the 36th AIEST congress, 31 August - 6 September 1986, Montreux, Switzerland. Publications de I'AIEST, Association Internationale d'Experts Scientifiques du Tourisme 27, 95-105

Hughes, A \& A. Lew. (2013). Real food in the US: local food initiative, government and tourism. In C. M. Hall \& S. Gössling, (Eds.). Sustainable Culinary Systems: Local Foods, Innovation, Tourism and Hospitality. Abingdon: Routledge, 64-84 
Jokinen, P., Järvelä, M., \& Puupponen, (2009). A. Local food systems and rural sustainability initiatives by small scale rural entrepreneurs in Finland. URL: http://www.mua.fi/SIRA_Files/downloads/ Arkisto/UA_lehti/2009/mua_2009_2_a_Jo kinen.pdf (accessed 3.3.2016)

Kearney, J. (2010). Food consumption trends and drivers. Philosophical Transactions of the Royal Society B: Biological Sciences 365, 2793-2807.

Kloppenburg, J., Hendrickson, J. \& Stevenson, G. (1996). Coming in to the Foodshed. Agriculture and Human Values 13, 33-42.

Larsen, S., Brun, W., Øgaard, T., \& Selstad, L. (2007). Subjective food-risk judgments in tourists. Tourism Management 28, 15551559.

Marsden, T. \& E. Smith. (2005). Ecological entrepreneurship: sustainable development in local communities through quality food production and local branding. Geoforum 36, 440-451.

Mehmetoglu, M., Ø. Normann (2013). What influences tourists' overall holiday experience? Tourism company products versus destination products. European Journal of Tourism Research 6(2), 183191

Meler, M, \& Cerović, Z. (2003). Food marketing in the function of tourist product development. British Food Journal 105, 175-192.

Momsen, J. (1998). Caribbean tourism and agriculture: New Linkages in the global era? In T. Klak (ed.) Globalization and Neoliberalism: The Caribbean context. Lanham MD, Rowan and Littlefield 115134

Murdoch, J., Marsden, T., \& Banks, J. (2000). Quality, nature, and embeddedness: some theoretical considerations in the context of the food sector. Economic Geography 76, 107-125.

Nelson, V. (2016). Peru's image as a culinary destination. Journal of Cultural Geography, 33(2), 208-228.

Nilsson, J. (2013). Nordic eco-gastronomy: the Slow Food concept in relation to Nordic Gastronomy. In C. M. Hall \& S. Gössling, (Eds.). Sustainable Culinary Systems: Local Foods, Innovation, Tourism and Hospitality. Abingdon, Routledge 189-204
Pauly, D., Christensen, V., Guénette, S., Pitcher, T. J., Sumaila, U. R., Walters, C., Watson, R. \& Zeller, D. (2002). Towards sustainability in world fisheries. Nature 418, 689-695.

Pauly, D. (2008). Global fisheries: a brief review. Journal of Biological ResearchThessaloniki 9, 3-9.

Pearson, D., Henryks, J., \& Jones, H. (2011). Organic food: What we know (and do not know) about consumers. Renewable Agriculture and Food Systems 26, 171-177.

Petrini, C. (2003). Slow food: The case for taste. Columbia University Press.

Pollan, M. (2007). The Omnivore's dilemma: A natural history of four meals. New York, Penguin.

Pratt, S. (2013). Minimising food miles: issues and outcomes in an ecotourism venture in Fiji. Journal of Sustainable Tourism 21, 1148-1165.

Robinson, R. \& Smith, C. (2002). Psychosocial and demographic variables associated with consumer intention to purchase sustainably produced foods as defined by the Midwest Food Alliance, Journal of Nutrition Education \& Behavior 34, 316-226.

Robertson, R. \& Getz, D. (2016). Food enthusiasts and tourism: Exploring food involvement dimensions. Journal of Hospitality \& Tourism Research, 40(4), 432-455.

Rogerson, C. M. (2012). Tourism-agriculture linkages in rural South Africa: Evidence from the accommodation sector. Journal of Sustainable Tourism 20, 477-495.

Roheim, C. A. (2009). An evaluation of sustainable seafood guides: implications for environmental groups and the seafood industry. Marine Resource Economics 24, 301-10.

Scarpato, R. (2002). Sustainable gastronomy as a tourist product. In A. Hjalager \& $\mathrm{G}$. Richards. Tourism and Gastronomy. London, Routledge 132-152

Schubert, F., Kandampully, J., Solnet, D., and Kralj, A. (2010). Exploring consumer perceptions of green restaurants in the US. Tourism and Hospitality Research 10, 286-300.

Sharpley, R. (2000). Tourism and sustainable development: Exploring the theoretical 
divide. Journal of Sustainable Tourism 8, 1-19.

Sims, R. (2009). Food, place and authenticity: Local food and the sustainable tourism experience. Journal of Sustainable Tourism, 17: 321-336.

Slocum, S. (2015). Local Food: Greening the tourism value chain. In V. Reddy and $\mathrm{K}$. Wilkes (eds), Tourism in the green economy. London: Routledge, 242-254

Sparks, B., Bowen, J., \& Klag, S. (2003). Restaurants and the tourist market. International Journal of Contemporary Hospitality Management 15, 6-13.

Telfer, D. J., \& Wall, G. (1996). Linkages between tourism and food production. Annals of tourism Research 23, 635-653.

Thompson, G. \& Kidwell, J. (1998). Explaining the choice of Organic produce: Cosmetic defects, prices, and consumer preferences. American Journal of Agricultural Economics 80, 277-287.
Timms, B. (2006). Caribbean agriculturetourism linkages in a neoliberal world. International Development Planning Review 28, 36-56.

Torres, R. (2002). Toward a better understanding of tourism and agriculture linkages in the Yucatan: Tourist food consumption and preferences. Tourism Geographies 4, 282-306.

Torres, R. \& J. Momsen. (2004). Challengers and potential for Linking tourism and agriculture to achieve pro-poor tourism objectives. Progress in Development Studies 4, 294-318.

Vermeir, I. \& Verbeke, W. (2006). Sustainable food consumption: Exploring the consumer "attitude-behavioral intention" gap. Journal of Agricultural and Environmental Ethics 19, 169-194. 